\title{
Molecular Weight, Solubility and Viscosity of $\beta$-Glucan Preparations from Barley Pearling Byproducts
}

(Berat Molekul, Keterlarutan dan Kelikatan Persediaan $\beta$-Glukan daripada Hasil Sampingan Hampas Barli)

\author{
YOUNG-TACK LEE*, PRADEEP PULIGUNDLA \& PAUL B. SCHWARZ
}

\begin{abstract}
$\beta$-Glucan, the representative dietary fibre component of barley, has received much attention, primarily due to its nutritional significance. In this study, $\beta$-glucans prepared from barley pearling byproducts were characterized with respect to their molecular weight, solubility and viscosity. Following the initial alkaline extraction, the crude $\beta$-glucan extract $(45 \%$ purity) was further purified to approximately $90 \%$. The isolated $\beta$-glucans exhibited a wide molecular weight range with peak molecular weight of less than $1 \times 10^{6}$ daltons. Solubilities of crude and purified $\beta$-glucans in water were lower than that of $\beta$-glucan in the native barley pearling byproducts. However, the aqueous solubility of purified $\beta$-glucan from pearlings was substantially higher than that of commercial $\beta$-glucan. Compared to the latter, purified $\beta$-glucan exhibited low apparent viscosity in aqueous solutions.
\end{abstract}

Keywords: Barley; $\beta$-glucan; molecular weight distribution; pearling byproduct; solubility; viscosity

ABSTRAK

$\beta$-Glukan, komponen wakil serabut diet barli telah mendapat banyak perhatian, terutamanya disebabkan oleh kepentingan pemakanan. Dalam kajian ini, $\beta$-glukan yang disediakan daripada hasil sampingan hampas barli telah dicirikan dengan berat molekul, keterlarutan dan kelikatan. Mengikut pengekstrakan beralkali asal, ekstrak mentah $\beta$-glukan (45\% ketulenan) telah dimurnikan lagi sehingga 90\%. $\beta$-glukan yang dipencilkan mempamerkan pelbagai julat berat molekul dengan puncak berat molekul kurang daripada $1 \times 10^{6}$ dalton. Keterlarutan $\beta$-glukan mentah dan tulen dalam air adalah lebih rendah daripada $\beta$-glukan dalam bahan sampingan hampas barli asli. Walau bagaimanapun, kebolehlarutan akueus $\beta$-glukan tulen daripada hampas adalah tinggi daripada $\beta$-glukan komersial. Berbanding dengan kedua, $\beta$-glukan tulen menunjukkan kelikatan yang rendah dalam larutan akueus.

Kata kunci: Barli; $\beta$-glukan; hasil sampingan hampas barli; kelikatan; keterlarutan; pengagihan berat molekul

\section{INTRODUCTION}

In Western countries, hulled barley is mainly used as animal feed and raw material for malt production in breweries. For direct human consumption, barley is ground, rollermilled, pearled, steamed, boiled, baked, extruded, roasted, flaked or cut into grits. In Korea and Japan, substantial quantities of barley are pearled, converting it into an edible rice extender.

Pearling is an abrasive milling process that gradually removes the seed coat (testa and pericarp), aleurone, subaleurone layers, outer endosperm and the germ to obtain polished grain (Zheng et al. 2000). About $30-40 \%$ of the total kernel weight is removed in the pearling process, with the resulting byproducts mainly used in animal feed (Seog et al.2002). These byproducts contain considerable amounts of bioactive compounds, such as $\beta$-glucans, tocopherols, tocotrienols and polyphenols (Panfili et al. 2008; Seog et al. 2002; Tamagawa et al. 1997; Wang et al. 1993). The aleurone cell walls of barley contain ca. $26 \%$ of $\beta$-glucans (Bacic \& Stone 1981). A non-uniform distribution of $\beta$-glucans in pearling byproducts has been reported (Bhatty 1997; Zheng et al. 2000).
Mixed-linkage $(1 \rightarrow 3),(1 \rightarrow 4)-\beta$-D-glucan (also referred to as $\beta$-glucan) is the major structural component of barley grain cell walls. Being the representative dietary fiber component of barley, this compound has received much attention, primarily due to its nutritional significance. $\beta$-Glucans have been reported to exhibit different physiological functions in humans in terms of reducing serum cholesterol levels (Newman et al. 1987) and providing a blood glucose-controlling effect by lowering the dietary glycemic load (Li et al. 2003; Wood et al. 1994, 1990). $\beta$-Glucans exist in either soluble or insoluble forms (Aman \& Graham 1987), with their solubility in water playing an important role in lowering cholesterol and postprandial serum glucose levels in humans and animals (Kahlon \& Chow 1997).

Soluble $\beta$-glucans show high viscosity in aqueous solution and may reduce the absorption rate of various nutrients by increasing viscosity (as a result of hydration in the digestive system) or by forming gel-state substances. Soluble barley $\beta$-glucans increase the viscosity of digesta in the intestinal tract and thereby slow down the rate of digestion and absorption of starch (Gaosong \& Vasanthan 
2000). The high viscosity of soluble $\beta$-glucans, resulting from hydration, is thought to be responsible for their biological activity (Izydorczyk et al. 2000). The physical properties of these carbohydrate polymers are reported to vary depending on the source and variety of barley and are related to molecular size and shape (Vaikousi et al. 2004). Milling, extraction, digestion and other processes can degrade $\beta$-glucans.

The objective of this research was to evaluate the molecular weight, solubility, and viscosity of $\beta$-glucans prepared from the industrially produced pearling byproducts of barley. The feasibility of producing high value-added products, e.g., $\beta$-glucans, from these byproducts could benefit the food processing industry.

\section{MATERIALS AND METHODS}

\section{MATERIALS}

Barley grains were pearled using 24 consecutive barley pearlers at Jung-won Industrial Co. (Bosung, Korea). Broken kernels and germ were separated from the pearling byproducts based on their specific gravity by aspiration and using a 16-mesh sieve, respectively. The resulting byproduct of barley pearling constituted $24 \% \mathrm{w} / \mathrm{w}$ (dry basis) of the total weight of barley. Commercial $\beta$-glucan was obtained from Megazyme International (Wicklow, Ireland).

\section{CHEMICAL ANALYSES}

Moisture, protein, lipid, ash and starch content were analyzed according to AACC methods (2000). The soluble dietary fiber (SDF), insoluble dietary fiber (IDF) and total dietary fiber (TDF) content was measured using a dietary fiber assay kit (Sigma Co., USA) according to Prosky's method (Prosky et al. 1988). Total $\beta$-glucan content was determined by the method of McCleary and GlennieHolmes (1985) using a $\beta$-glucan assay kit (Megazyme International, Wicklow, Ireland).

\section{EXTRACTION AND PURIFICATION OF $\beta$-GLUCAN}

$\beta$-Glucan was extracted according to the methods of Wood et al. (1977) as modified by Lee (1992). Barley pearling byproduct was mixed with distilled water and the solution $\mathrm{pH}$ was immediately adjusted to 10.0 with $20 \%$ $(\mathrm{w} / \mathrm{v})$ sodium carbonate. The suspension was subjected to extraction by vigorous stirring at $45^{\circ} \mathrm{C}$ for $30 \mathrm{~min}$ and the extract was centrifuged. The $\mathrm{pH}$ of the cooled supernatant was adjusted to 4.0 using $2 \mathrm{M} \mathrm{HCl}$ and the solution was centrifuged $(15,000 \times \mathrm{g}, 15 \mathrm{~min})$ to remove the protein. The supernatant was diluted with an equal volume of isopropyl alcohol (IPA). The precipitate was allowed to settle overnight and was collected by centrifugation $(21,000 \times \mathrm{g}, 20 \mathrm{~min})$, resuspended in IPA and disintegrated with a homogenizer (Taitec, Model HP-93F, Japan). The sample was washed with IPA on filter paper and dried at room temperature for two days to obtain crude $\beta$-glucan.
The resultant crude $\beta$-glucan was dissolved in distilled water $(0.3 \% \mathrm{w} / \mathrm{v})$ by heating at $90^{\circ} \mathrm{C}$ for $1 \mathrm{~h}$. Undissolved material was removed by centrifugation. The crude $\beta$-glucan was purified by precipitation with aqueous ammonium sulfate $(30 \% \mathrm{w} / \mathrm{v})$. The precipitate was redissolved in water by heating in a boiling water bath and the solution was cooled. $\beta$-Glucan was reprecipitated by addition of $50 \%(\mathrm{v} / \mathrm{v})$ acetone and centrifuged. The final precipitate was redissolved in water and dialyzed using a dialysis membrane (molecular weight cut-off [MWCO]: $6,000-8,000$, Spectrum Medical Industry, USA). The $\mathrm{pH}$ of the dialyzed solution was adjusted to 6.9 and allowed to react with $\alpha$-amylase (1013 U/100 $\mathrm{mL} \beta$-glucan solution) at $40^{\circ} \mathrm{C}$ for $1 \mathrm{~h}$. The solution was cooled, adjusted to $\mathrm{pH} 7.5$ and mixed with protease (70 U/100 $\mathrm{mL} \beta$-glucan solution), allowing the mixture to react at $40^{\circ} \mathrm{C}$ for $1 \mathrm{~h}$. After enzyme inactivation by heating, the solution was dialyzed against distilled water and freeze-dried for $96 \mathrm{~h}$ to prepare the purified $\beta$-glucan.

\section{MOLECULAR WEIGHT DISTRIBUTION}

The molecular weight was estimated by gel filtration chromatography. $\beta$-Glucan $(15 \mathrm{mg}$ ) was dissolved in $0.25 \mathrm{M}$ sodium chloride $(5 \mathrm{~mL})$ and filtered through a $0.45 \mu \mathrm{m}$ membrane filter. A portion of the filtrate (1.2 $\mathrm{mL}$ ) was fractionated on a $2.6 \times 90$ Sephacryl S-500 SF column (Pharmacia Fine Chemicals, Uppsala, Sweden). The column was eluted with $0.25 \mathrm{M}$ sodium chloride at a flow rate of $1.76 \mathrm{~mL} / \mathrm{min}$ and fractions of $5 \mathrm{~mL}$ were collected. The column was calibrated with standard dextran $\mathrm{T}$ fractions, T10, T70, T500 and T2000. The molecular weights $\left(\mathrm{M}_{\mathrm{w}}\right)$ of the dextran standards, as quoted by the supplier, were $1 \times 10^{4}, 7 \times 10^{4}, 5 \times 10^{5}$ and $2 \times 10^{6}$ daltons, respectively. The concentration of $\beta$-glucan in each fraction was determined by the anthrone colorimetric assay (York et al. 1986).

\section{SOLUBILITY OF $\beta$-GLUCAN}

The solubility of $\beta$-glucan (unpurified) in the native barley pearling byproduct was determined by mixing $100 \mathrm{mg}$ of the sample with $10 \mathrm{~mL}$ of distilled water and subjecting it to continuous shaking for 30 and $120 \mathrm{~min}$ at 25,45 and $65^{\circ} \mathrm{C}$, followed by centrifugation at $10,000 \times \mathrm{g}$ for $5 \mathrm{~min}$. $\beta$-Glucan content was determined for an aliquot $(0.1 \mathrm{~mL})$ of the supernatant, with solubility calculated as the percentage of the total $\beta$-glucan content in the pearling byproduct. The solubility of crude and purified $\beta$-glucan was determined using the same procedure, but the weight of the sample and the volume of distilled water added were $10 \mathrm{mg}$ and $1 \mathrm{~mL}$, respectively.

\section{MEASUREMENT OF $\beta$-GLUCAN VISCOSITY}

Viscosity measurements were performed with a Haake Rotovisco RV20 viscometer. The viscosity was mathematically defined in absolute units by preset speed and measured torque. The flow behavior of $\beta$-glucan 
solutions was determined by measuring shear stress at various shear rates. A coaxial cylinder sensor (Sensor system NV, Germany) was used for shear rates between $0-800 \mathrm{~s}^{-1}$. $\beta$-Glucan solutions $(1-2 \%, \mathrm{w} / \mathrm{v})$ were tested at $23^{\circ} \mathrm{C}$.

\section{RESULTS AND DISCUSSION}

\section{CHEMICAL COMPOSITION OF PEARLING BYPRODUCT AND THE PREPARED $\beta$-GLUCANS}

The mean chemical compositions of barley pearling byproduct are shown in Table 1 . In addition to hulls, the pericarp, testa, aleurone layer and outer endosperm were gradually removed by pearling. The barley pearlings used in this experiment contained $32.31 \%$ starch, $16.23 \%$ protein, $8.57 \%$ lipid and $2.79 \%$ ash.

TABLE 1. Chemical composition of barley pearling byproduct $(n=3)$

\begin{tabular}{lc}
\hline Component & $\%(w / w$, dry weight basis $)$ \\
\hline Moisture & $8.83 \pm 0.71$ \\
Starch & $32.31 \pm 1.80$ \\
Protein & $16.23 \pm 0.88$ \\
Fat & $8.57 \pm 1.19$ \\
Ash & $2.79 \pm 0.21$ \\
Total dietary fiber & $35.10 \pm 1.47$ \\
Soluble dietary fiber & $14.67 \pm 0.51$ \\
Insoluble dietary fiber & $20.43 \pm 1.78$ \\
Total $\beta$-glucan & $4.78 \pm 0.21$ \\
\hline
\end{tabular}

While the TDF content of barley pearlings was $35.10 \%$, the SDF and IDF contents were $14.67 \%$ and $20.43 \%$, respectively. Bhatty (1993) reported a ca. 1:3 ratio of SDF:TDF in bran obtained from roller-milled barley, whereas the pearling sample in this study showed a slightly higher SDF:TDF ratio.

The $\beta$-glucan content of barley pearlings was $4.78 \%$, not significantly different from ca. $2-8 \%$ total $\beta$-glucan in whole barley varieties. Miller and Fulcher (1994) reported that $\beta$-glucan in barley was more uniformly distributed throughout the endosperm compared to oats, where a high concentration of $\beta$-glucan was found in the subaleurone, particularly for low- $\beta$-glucan oats. However, considerable variation in $\beta$-glucan distribution depending on barley genotype has been reported (Oscarsson et al. 1997). Zheng et al. (2000) indicated that $\beta$-glucan content was relatively high in the subaleurone region for low- $\beta$-glucan barley but not for high- $\beta$-glucan barley, suggesting that the pearling byproduct was a good source of $\beta$-glucan.

Table 2 demonstrates the purity levels of $\beta$-glucans at different stages of extraction and purification from the barley pearling byproduct. Crude $\beta$-glucan separated by alkaline extraction was $45 \%$ pure, which is relatively low compared to crude $\beta$-glucan extracted from whole barley (60-70\%) using the method of Wood et al. (1977). The $\beta$-glucan content (purity) in purified $\beta$-glucan was as high as $\sim 90 \%$.

\section{MOLECULAR WEIGHT DISTRIBUTION OF $\beta$-GLUCANS}

Relative molecular weight distributions of $\beta$-glucan samples are shown in Figure 1. Gel filtration using

TABLE 2. Chemical composition (\% dry weight basis) of $\beta$-glucan preparations from barley pearling byproduct $(n=3)$

\begin{tabular}{lccc}
\hline & $\begin{array}{c}\text { Crude } \\
\beta \text {-glucan }\end{array}$ & $\begin{array}{c}\text { Purified } \\
\beta \text {-glucan }\end{array}$ & $\begin{array}{c}\text { Commercial } \\
\beta \text {-glucan }\end{array}$ \\
\hline$\beta$-Glucan & $44.99 \pm 2.05$ & $90.43 \pm 1.98$ & $93.28 \pm 2.18$ \\
Protein & $4.22 \pm 0.81$ & $<0.1$ & $<0.1$ \\
Moisture & $6.72 \pm 1.22$ & $7.47 \pm 0.60$ & $8.54 \pm 1.06$ \\
\hline
\end{tabular}

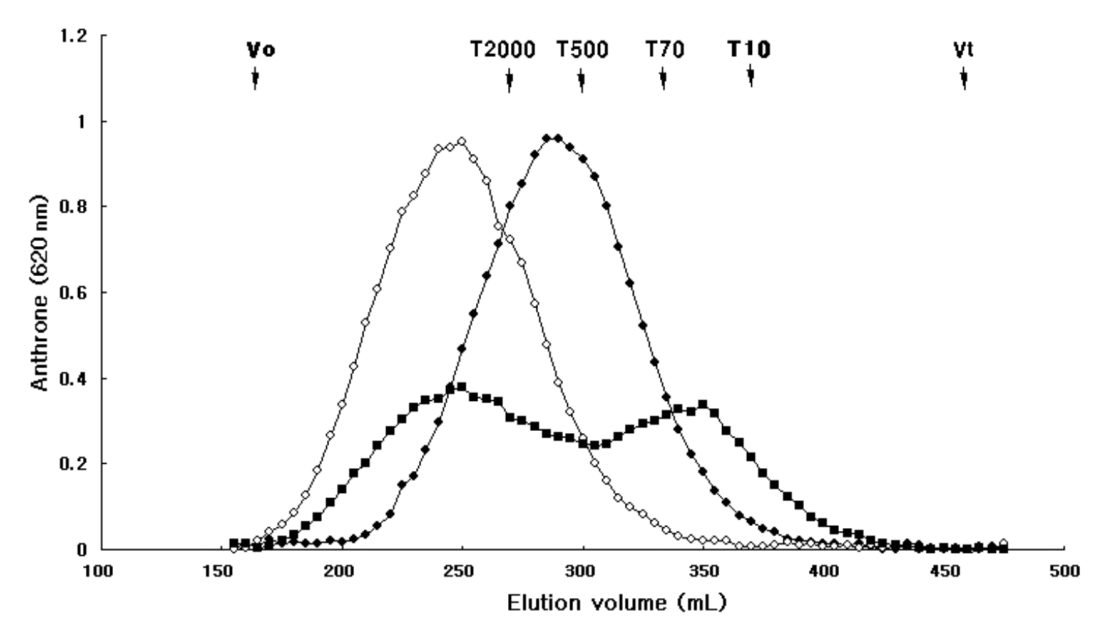

FIGURE 1. Relative molecular weight distributions of $\beta$-glucan preparations from barley pearling byproducts $(\diamond$ - commercial $\beta$-glucan, $\diamond-$ purified $\beta$-glucan, $\bullet-$ crude $\beta$-glucan $)$ 
the Sephacryl S-500 column showed that the $\beta$-glucan preparations had a wide molecular weight range. The column was calibrated using standard dextran T-fractions of known molecular weights. The peak molecular weight of commercial $\beta$-glucan exceeded $2 \times 10^{6}$ daltons. The average $\mathrm{M}_{\mathrm{w}}$ of commercial $\beta$-glucans can vary considerably between batches, due to variations in $\mathrm{M}_{\mathrm{w}}$ profiles and purity (McCleary 1988). The peak molecular weight of purified $\beta$-glucan from barley pearlings appeared to be less than $1 \times 10^{6}$ daltons. The molecular weight of barley $\beta$-glucan ranged between 0.15 and $2.5 \times 10^{6} \mathrm{~g} / \mathrm{mol}$ (Beer et al. 1997; Wood et al. 1991). Estimation of molecular weight distribution by gel filtration chromatography showed values of approximately $10^{5}-10^{7}$ for the water-soluble $\beta$-glucan at $65^{\circ} \mathrm{C}$ (Forrest \& Wainright 1977).

The average molecular weight and concentration of $\beta$-glucan extracted from oats and barley varied between studies (Beer et al. 1997; Wood et al. 1991). The different samples used were one reason for this observation, another reason being the different extractabilities of $\beta$-glucan, depending on the extraction methods used (Rimsten et al. 2003).

\section{SOLUBILITY OF $\beta$-GLUCAN PREPARATIONS FROM BARLEY PEARLING BYPRODUCT}

The solubilities of $\beta$-glucan in the native byproduct of barley pearling and of the $\beta$-glucan prepared at 25,45 and $65^{\circ} \mathrm{C}$ are presented in Table 3 . The solubility increased with increasing temperature and time, with the solubilities of native barley pearling byproduct after $120 \mathrm{~min}$ at 25,45 and $65^{\circ} \mathrm{C}$ being $2.43,2.61$ and $2.84 \%$, respectively, based on sample weight. This indicated that the soluble $\beta$-glucan fraction at 25,45 and $65^{\circ} \mathrm{C}$ accounted for $50.84,54.60$ and $59.41 \%$ of total $\beta$-glucan in the native barley pearling byproduct, respectively.

The non-extractability of $\beta$-glucan in the alkaline extraction process could be attributed to numerous factors, including differences in bran particle size, different size distributions of $\beta$-glucan, different or tighter cross-linking of barley $\beta$-glucan in cell walls, together with cultivar, stage of kernel development and growing conditions affecting the content and solubility of $\beta$-glucan. Woodward et al. (1988) reported that the solubility of $\beta$-glucan was largely dependent on small differences in structural features that alter the ability of chains to align and form relatively stable molecular aggregates. The structural variations of $\beta$-glucans are reported to be associated with their differential solubility and extractability properties (Lazaridou et al. 2007).

The solubilities of crude $\beta$-glucan at 25,45 and $65^{\circ} \mathrm{C}$ were $13.5,16.1$ and $20.5 \%$, respectively, based on sample weight. This indicated that soluble $\beta$-glucan at 25,45 and $65^{\circ} \mathrm{C}$ accounted for $29.9,35.8$ and $45.6 \%$ of total $\beta$-glucan in the crude sample, respectively. The solubilities of purified $\beta$-glucan at 25,45 and $65^{\circ} \mathrm{C}$ were $34.3,39.8$ and $59.8 \%$, respectively, based on sample weight. This also indicated that soluble $\beta$-glucan at 25,45 and $65^{\circ} \mathrm{C}$ accounted for $38.4,44.5$ and $66.9 \%$ of total $\beta$-glucan in the purified sample, respectively. The solubility of crude and purified $\beta$-glucan was lower than that of $\beta$-glucan in the native barley pearling byproduct.

The differences in primary and secondary solubilities of native $\beta$-glucan may be attributed to cultivar-dependent primary structural differences (Gaosong \& Vasanthan $2000)$. In addition, the solubility of commercial $\beta$-glucan was substantially lower than that of purified $\beta$-glucan from barley pearlings.

\section{VISCOSITY OF B-GLUCAN SOLUTION}

Flow curves of $\beta$-glucan preparations at $1-2 \%$ concentrations are shown in Figure 2. Compared to commercial $\beta$-glucan, purified $\beta$-glucan yielded aqueous solutions of lower apparent viscosity, probably due to its reduced molecular weight. Besides $M_{w}$, the apparent viscosity of $\beta$-glucan solutions is a function of polymer concentration, chain conformation and intermolecular interactions (Izydorczyk \& Dexter 2008). According to Woodward et al. (1983), the $\beta$-glucan molecule can be stretched into a fully extended

TABLE 3. Solubility ( $\%$ dry basis) of $\beta$-glucan preparations from barley pearling byproduct $(n=3)$

\begin{tabular}{|c|c|c|c|c|c|c|}
\hline & \multicolumn{2}{|c|}{$25^{\circ} \mathrm{C}$} & \multicolumn{2}{|c|}{$45^{\circ} \mathrm{C}$} & \multicolumn{2}{|c|}{$65^{\circ} \mathrm{C}$} \\
\hline & $30 \mathrm{~min}$ & $120 \mathrm{~min}$ & $30 \mathrm{~min}$ & $120 \mathrm{~min}$ & $30 \mathrm{~min}$ & $120 \mathrm{~min}$ \\
\hline Barley pearling & & & & & & \\
\hline$\%$ of barley pearling & $1.67 \pm 0.20$ & $2.43 \pm 0.09$ & $2.16 \pm 0.09$ & $2.61 \pm 0.10$ & $2.38 \pm 0.09$ & $2.84 \pm 0.05$ \\
\hline$\%$ of total $\beta$-glucan & $34.94 \pm 4.10$ & $50.84 \pm 1.83$ & $45.19 \pm 1.79$ & $54.60 \pm 2.01$ & $49.87 \pm 1.79$ & $59.41 \pm 1.12$ \\
\hline Crude form & & & & & & \\
\hline$\%$ of $\beta$-glucan form & $11.08 \pm 1.55$ & $13.46 \pm 2.61$ & $15.94 \pm 2.89$ & $16.13 \pm 3.17$ & $18.04 \pm 3.04$ & $20.52 \pm 3.60$ \\
\hline$\%$ of total $\beta$-glucan & $24.61 \pm 3.43$ & $29.90 \pm 6.24$ & $35.41 \pm 7.52$ & $35.83 \pm 7.58$ & $40.07 \pm 6.19$ & $45.60 \pm 7.65$ \\
\hline Purified form & & & & & & \\
\hline$\%$ of $\beta$-glucan form & $32.43 \pm 1.12$ & $34.26 \pm 2.34$ & $38.84 \pm 3.56$ & $39.77 \pm 4.83$ & $43.82 \pm 3.10$ & $59.75 \pm 4.24$ \\
\hline$\%$ of total $\beta$-glucan & $36.30 \pm 1.25$ & $38.35 \pm 3.09$ & $43.48 \pm 5.06$ & $44.52 \pm 6.60$ & $49.05 \pm 4.42$ & $66.89 \pm 5.11$ \\
\hline Commercial form & & & & & & \\
\hline$\%$ of $\beta$-glucan form & $23.42 \pm 3.29$ & $25.49 \pm 2.30$ & $26.36 \pm 2.81$ & $27.25 \pm 3.33$ & $36.27 \pm 1.94$ & $40.77 \pm 3.11$ \\
\hline$\%$ of total $\beta$-glucan & $25.49 \pm 3.58$ & $27.74 \pm 2.76$ & $28.69 \pm 3.23$ & $29.66 \pm 4.06$ & $39.48 \pm 2.37$ & $44.37 \pm 4.18$ \\
\hline
\end{tabular}




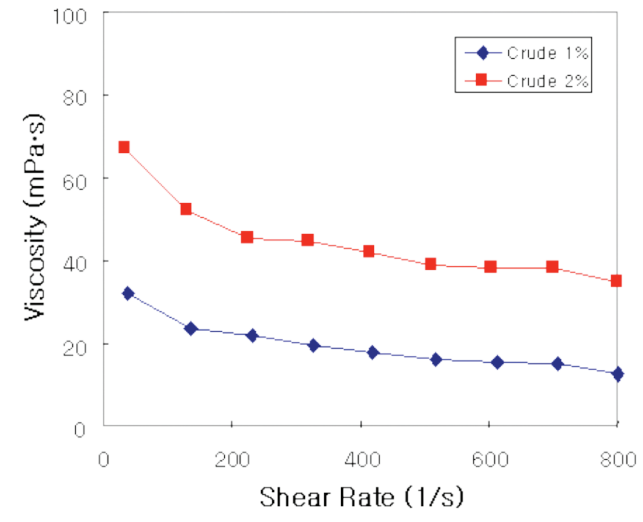

(a)

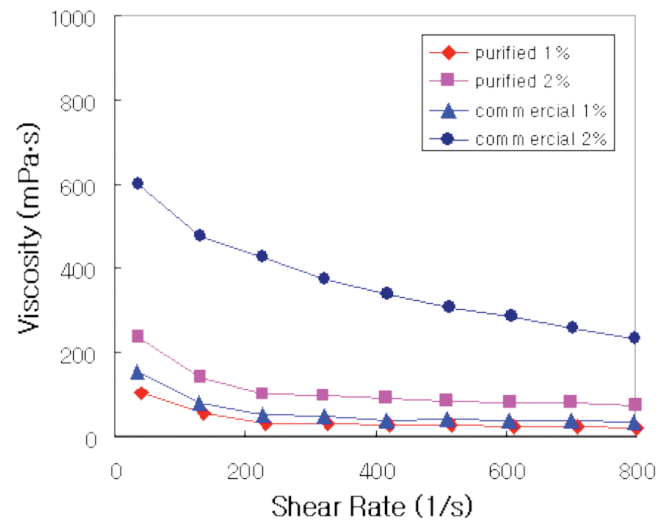

(b)

FIGURE 2. Apparent viscosities of crude (a) and purified (b) $\beta$-glucan from barley pearlings and the commercial purified $\beta$-glucan (1 and $2 \%, \mathrm{w} / \mathrm{v}$, aqueous solutions)

conformation, with the polysaccharide having a wormlike conformation in aqueous solution. For the same shear, an increase in solution concentration significantly increases the apparent viscosity (Figure 2). Barley $\beta$-glucans from the pearling byproduct exhibited typical pseudoplastic flow properties. At any given $\beta$-glucan concentration, a viscosity decrease or shear-thinning flow can be observed with increasing shear rate, a behavior typical for viscoelastic fluids (Lazaridou et al. 2007).

\section{CONCLUSION}

In conclusion, barley pearlings were found to be rich sources of dietary fiber, starch and protein, along with appreciable amounts of $\beta$-glucan. The molecular weights of the $\beta$-glucan preparations were widely variable, with the peak molecular weight of purified $\beta$-glucan being less than $1 \times 10^{6}$ daltons. The fraction of soluble $\beta$-glucan was relatively high in native barley pearlings, compared to amounts in the crude extract and purified preparation. Therefore, it can be concluded that the solubility of $\beta$-glucan polymer decreases upon isolation, but is still higher than that of the commercial $\beta$-glucan isolated from whole barley grain. However, the purified $\beta$-glucan from pearlings exhibited relatively low apparent viscosity compared to that of commercial purified $\beta$-glucan.

\section{REFERENCES}

AACC. 2000. Approved Methods of the AACC. 10th ed. St. Paul, MN: American Association of Cereal Chemists.

Aman, P. \& Graham, H. 1987. Mixed-linked $\beta-(1 \rightarrow 3)$, $(1 \rightarrow 4)$-D-glucans in the cell walls of barley and oats-chemistry and nutrition. Scandinavian Journal of Gastroenterology 22: 47-51.

Bacic, A. \& Stone, B.A. 1981. Chemistry and organization of aleurone cell wall components from wheat and barley. Australian Journal of Plant Physiology 8: 475-495.

Beer, M.U., Wood, P.J., Weisz, J. \& Fillion, N. 1997. Effect of cooking and storage on the amount and molecular weight of
$(1 \rightarrow 3),(1 \rightarrow 4)-\beta$-D-glucan extracted from oat products by an in vitro digestion system. Cereal Chemistry 74: 705-709.

Bhatty, R.S. 1997. Milling of regular and waxy starch hull-less barley for the production of bran and flour. Cereal Chemistry 74: 693-699.

Bhatty, R.S. 1993. Extraction and enrichment of $(1 \rightarrow 3)$, $(1 \rightarrow 4)-\beta$-D-glucan from barley and oat brans. Cereal Chemistry 70: 73-77.

Forrest, I.S. \& Wainwright, T. 1977. The mode of binding of $\beta$-glucans and pentosans in barley endosperm cell walls. Journal of the Institute of Brewing 83: 279-286.

Gaosong, J. \& Vasanthan, T. 2000. Effect of extrusion cooking on the primary structure and water solubility of beta-glucans from regular and waxy barley. Cereal Chemistry 77: 396-400.

Izydorczyk, M.S. \& Dexter, J.E. 2008. Barley $\beta$-glucans and arabinoxylans: Molecular structure, physicochemical properties, and uses in food products-a Review. Food Research International 41: 850-868.

Izydorczyk, M.S., Storsley, J., Labossiere, D., MacGregor, A.W. \& Rossnagel, B.G. 2000. Variation in total and soluble $\beta$-glucan content in hulless barley: Effects of thermal, physical, and enzymatic treatments. Journal of Agricultural and Food Chemistry 48: 982-989.

Kahlon, T.S. \& Chow, F.I. 1997. Hypocholesterolemic effects of oat, rice, and barley dietary fibers and fractions. Cereal Food World 42: 86-92.

Lazaridou, A., Biliaderis, C.G. \& Izydorczyk, M.S. 2007. Cereal $\beta$-glucans: Structures, physical properties, and physiological functions. In Functional Food Carbohydrates, edited by Biliaderis, C.G. \& Izydorczyk, M.S. Boca Raton: CRC Press, Taylor \& Francis Group. pp. 1-72.

Lee, Y.T. 1992. $\beta$-Glucans from hull-less barley: Isolation, chemical and rheological characterization and utilization as a food gum. PhD. dissertation, North Dakota State Univ., USA (Unpublished).

Li, J., Kaneko, T., Qin, L.Q., Wang, J. \& Wang, Y. 2003. Effects of barley intake on glucose tolerance, lipid metabolism, and bowel function in women. Nutrition 19: 11-12.

McCleary, B.V. 1988. Purification of $(1 \rightarrow 3),(1 \rightarrow 4)-\beta$-D-glucan from barley flour. In Methods in Enzymology, edited by Wood, W.A. \& Kellogg, S.T. San Diego: Academic Press. 160: 511-514. 
McCleary, B.V. \& Glennie-Holmes, M. 1985. Enzymatic quantification of $(1 \rightarrow 3),(1 \rightarrow 4)-\beta$-D-glucan in barley and malt. Journal of the Institute of Brewing 91: 285-295.

Miller, S.S. \& Fulcher, R.G. 1994. Distribution of $(1 \rightarrow 3)$, $(1 \rightarrow 4)-\beta$-D-glucan in kernels of oat and barley using microspectroflourometry. Cereal Chemistry 71: 64-68.

Newman, R.K., Newman, C.W., Fadel, J. \& Graham, H. 1987. Nutritional implications of beta-glucans in barley. Barley Genetics V: 773-780.

Oscarsson, M., Parkkonen, T., Autio, K. \& Aman, P. 1997. Composition and microstructure of normal, waxy and highamylose barley samples. Journal of Cereal Science 26: 259-264.

Panfili, G., Fratianni, A., Criscio, T.D. \& Marconi, E. 2008. Tocol and $\beta$-glucan levels in barley varieties and in pearling by-products. Food Chemistry 107: 84-91.

Prosky, L., Asp, N., Sweizer, T.F., Devries, J. \& Furda, I. 1988. Determination of insoluble, soluble, and total dietary fiber in foods and food products: Interlaboratory study. Journal of the Association of Official Analytical Chemists 71: 1017-1023.

Rimsten, L., Haraldsson, A.K., Andersson, R., Alminger, M., Sandberg, A.S. \& Aman, P. 2003. Effects of malting on $\beta$-glucanase and phytase activity in barley grain. Journal of the Science of Food and Agriculture 82: 904-912.

Seog, H.M., Seo, M.S., Kim, Y.S. \& Lee, Y.T. 2002. Physicochemical properties of barley bran, germ and broken kernel as pearling by-products. Food Science and Biotechnology 11: 623-627.

Tamagawa, K., Iizuka, S., Fukushima, S., Endo, Y. \& Komiyama, Y. 1997. Antioxidative activity of polyphenol extracts from barley bran. Nippon Shokuhin Kagaku Kogaku Kaishi 44: 512-515

Vaikousi, H., Biliaderis, C.G. \& Izydorczyk, M.S. 2004 . Solution flow behavior and gelling properties of water-soluble barley $(1 \rightarrow 3,1 \rightarrow 4)$ - $\beta$-glucans varying in molecular size. Journal of Cereal Science 39: 119-137.

Wang, L., Xue, Q., Newman, R.K. \& Newman, C.W. 1993. Enrichment of tocopherols, tocotrienols, and oil in barley fractions by milling and pearling. Cereal Chemistry 70: 499-501.

Wood, P.J., Braaten, J.T., Scott, F.W., Riedel, D. \& Poste, L.M. 1990. Comparisons of viscous properties of oat and guar gum and the effects of these and oat bran on glycemic index. Journal of Agricultural and Food Chemistry 38: 753-757.

Wood, P.J., Braaten, J.T., Scott, F.W., Riedel, K.D., Wolynetz, M.S.\& Collins, M.W. 1994. Effect of dose and modification of viscous properties of oat gum on blood glucose and insulin following an oral glucose load. British Journal of Nutrition 72: 731-743.
Wood, P.J., Weisz, J. \& Blackwell, B.A. 1991. Molecular characterization of cereal $\beta$-D-glucans. Structural analysis of oat $\beta$-D-glucan and rapid structural evaluation of $\beta$-Dglucans from different sources by high performance liquid chromatography of oligosaccharides released by lichenase. Cereal Chemistry 68: 31-39.

Woodward, J.R., Phillips, D.R. \& Fincher, G.B. 1988. Watersoluble $(1 \rightarrow 3,1 \rightarrow 4)$ - $\beta$-D-glucans from barley (Hordeum vulgare) endosperm. IV. Comparison of 40 and $65^{\circ} \mathrm{C}$ soluble fractions. Carbohydrate Polymers 8: 85-97.

Woodward, J.R., Fincher, G.B. \& Stone, B.A. 1983. Water-soluble $(1 \rightarrow 3),(1 \rightarrow 4)-\beta-D-$ glucans from barley (Hordeum vulgare) endosperm. II. Fine structure. Carbohydrate Polymers 3: 207-225.

Wood, P.J., Paton, D. \& Siddiqui, I.R. 1977. Determination of $\beta$-glucan in oats and barley. Cereal Chemistry 54: 524-533.

York, W.S., Darvill, A.G., McNell, M., Stevenson, T. \& Albersheim, P. 1986. Isolation and characterization of plant cell walls and cell wall components. In Methods in Enzymology, edited by Weissbach, A. \& Weissbach, H. New York: Academic Press, Inc. 118: 3-41.

Zheng, G.H., Rossnagel, B.G., Tyler, R.T. \& Bhatty, R.S. 2000. Distribution of $\beta$-glucans in the grain of hull-less barley. Cereal Chemistry 77: 140-144.

Young-Tack Lee* \& Pradeep Puligundla Department of Food Science and Biotechnology Gachon University, Seongnam 13120

Korea

Paul B. Schwarz

Department of Plant Sciences

North Dakota State University

Fargo, ND 58108-6050

USA

*Corresponding author; email: ytlee@gachon.ac.kr

Received: 29 October 2015

Accepted: 17 October 2016 